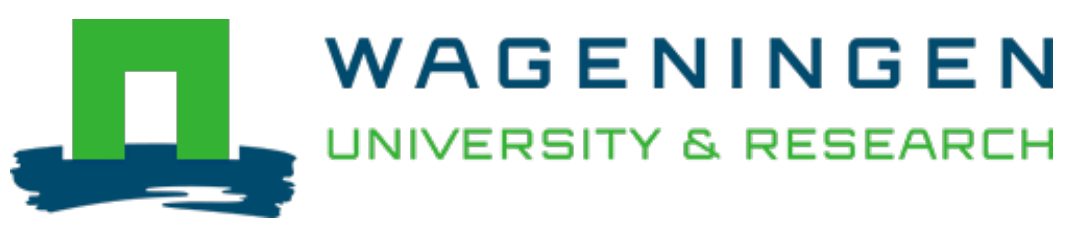

\title{
Diversity and distribution of pathotypes of the soybean rust fungus Phakopsora pachyrhizi in East Africa
}

\author{
Plant Pathology \\ Murithi, Harun M.; Soares, Rafael M.; Mahuku, George; Esse, Peter; Joosten, Matthieu H.A.J. \\ https://doi.org/10.1111/ppa.13324
}

This article is made publicly available in the institutional repository of Wageningen University and Research, under the terms of article $25 \mathrm{fa}$ of the Dutch Copyright Act, also known as the Amendment Taverne. This has been done with explicit consent by the author.

Article 25 fa states that the author of a short scientific work funded either wholly or partially by Dutch public funds is entitled to make that work publicly available for no consideration following a reasonable period of time after the work was first published, provided that clear reference is made to the source of the first publication of the work.

This publication is distributed under The Association of Universities in the Netherlands (VSNU) 'Article $25 \mathrm{fa}$ implementation' project. In this project research outputs of researchers employed by Dutch Universities that comply with the legal requirements of Article $25 \mathrm{fa}$ of the Dutch Copyright Act are distributed online and free of cost or other barriers in institutional repositories. Research outputs are distributed six months after their first online publication in the original published version and with proper attribution to the source of the original publication.

You are permitted to download and use the publication for personal purposes. All rights remain with the author(s) and / or copyright owner(s) of this work. Any use of the publication or parts of it other than authorised under article $25 \mathrm{fa}$ of the Dutch Copyright act is prohibited. Wageningen University \& Research and the author(s) of this publication shall not be held responsible or liable for any damages resulting from your (re)use of this publication.

For questions regarding the public availability of this article please contact openscience.library@,wur.nl 


\title{
Diversity and distribution of pathotypes of the soybean rust fungus Phakopsora pachyrhizi in East Africa
}

\author{
Harun M. Murithi ${ }^{1}$ (D) | Rafael M. Soares ${ }^{2}$ | George Mahuku ${ }^{1}$ (D) | H. Peter van Esse ${ }^{3}$ | \\ Matthieu H. A. J. Joosten ${ }^{4}$ (II)
}

${ }^{1}$ International Institute of Tropical Agriculture, Dar es Salaam, Tanzania

${ }^{2}$ Embrapa Soja, Londrina, Parana, Brazil

${ }^{3}$ The Sainsbury Laboratory, Norwich Research Park, Norwich, UK

${ }^{4}$ Laboratory of Phytopathology, Wageningen University and Research, Wageningen, Netherlands

\section{Correspondence}

Matthieu H. A. J. Joosten, Laboratory of Phytopathology, Wageningen University and Research, 6700 AA Wageningen, Netherlands.

Email: matthieu.joosten@wur.nl

Funding information

Lukas Brader Fellowship; International Institute of Tropical Agriculture (IITA); 2Blades Foundation

\begin{abstract}
Phakopsora pachyrhizi is a biotrophic fungus that causes rust on soybean, leading to devastating yield losses. Development of resistant cultivars for deployment in different geographic regions requires a comprehensive understanding of the prevalent P. pachyrhizi pathotypes. To determine the pathotypes existing in four East African countries, 65 isolates were tested on 11 soybean host differentials. In addition, the virulence spectrum of isolates collected from the same region over multiple years was compared. The majority of the isolates (54\%) belonged to pathotype 1000 , which was found in all countries. The pathotypes with the most complex virulence spectrum, which comprised isolates from Kenya and Malawi, were virulent on four differentials. All pathotypes were virulent on soybean genotypes carrying the Rpp1 resistance gene to P. pachyrhizi, but they were avirulent on cultivars carrying the Rpp1b, Rpp2, or Rpp3 gene, as well as on cultivar No6-12-1 that carries Rpp2, Rpp4, and Rpp5. Two of the pathotypes were virulent on cultivar UG 5 that carries Rpp1 and Rpp3 and on Hyuuga that carries Rpp3 and Rpp5. The isolates collected from different countries differed in their virulence spectrum across the years. Shannon's index $(H)$ and Simpson's index $(S)$ of diversity indicated that the isolates from Malawi were more diverse $(H=1.55, S=0.90)$ while those from Uganda had lower diversity $(H=0.78, S=0.46)$. The Rpp genes that were found to provide resistance to all pathotypes of $P$. pachyrhizi can be employed for soybean breeding aimed at durable rust resistance.
\end{abstract}

KEYWORDS

pathotype, Phakopsora pachyrhizi, Rpp gene, soybean rust, virulence diversity

\section{INTRODUCTION}

Soybean is a legume crop of significant and increasing importance for Africa. It contains up to $40 \%$ high-quality proteins and $20 \%$ oil, making it suitable for human consumption and livestock feeding. In sub-Saharan Africa, about 6.8 million households grow soybean and the production is predicted to increase at a rate of $2 \%-3 \%$ per annum (Abate et al.,

H. P. van Esse and M. H. A. J. Joosten contributed equally to this manuscript. 
Soybean rust, caused by the biotrophic fungus Phakopsora pachyrhizi, is a major disease of soybean. It has been recognized as one of the most important fungal pathogens worldwide (Dean et al., 2012) because of its spread across soybean-growing regions and the potential to devastate soybean yield. The fungus produces numerous urediniospores that are easily dispersed over short (Wen et al., 2017) and long (Isard et al., 2007) distances by wind currents, leading to new infections. Soybean rust was first observed in Africa in 1996 (Kawuki et al., 2003) and has so far spread to more than 10 countries in the continent (Murithi et al., 2015). Losses from soybean rust infection range from $10 \%$ to $80 \%$ worldwide (Levy, 2005), raising concerns about its impact on the rapidly growing soybean sector in Africa. Lesions on soybean leaves caused by the fungus can result in complete defoliation, reducing the photosynthetic capacity, and leading to fewer pods and smaller seeds (Kumudini et al., 2008). Huge losses have been reported in countries like Brazil, where in the 2011/12 growing season grain losses were estimated at over $\$ 192$ million, while the costs of controlling it were approximately $\$ 1.54$ billion (Godoy et al., 2016).

Pathotypes are groups of isolates that are classified based on their infection type (IT) on a set of host differentials carrying specific or combinations of resistance genes. For $P$. pachyrhizi, a tan-coloured (TAN) lesion with abundant sporulation indicates susceptibility, while reddish brown (RB) lesions with little to no sporulation and immune (IM) reactions signify resistance (Paul et al., 2015). Pathotypes of $P$. pachyrhizi were described for the first time in Taiwan based on the IT caused by nine different isolates on six soybean genotypes and five other legumes. Each pathotype induced an identical IT on plants carrying specific resistance loci (Lin, 1966). Since then, soybean host differentials have been used for characterization of pathogenic variability among $P$. pachyrhizi isolates across the globe. The host differentials used in different studies may vary, but the most commonly used hosts are six carrying well-characterized P. pachyrhizi resistance (Rpp) loci, namely Rpp1 (McLean \& Byrth, 1980), Rpp2 (Bromfield \& Hartwig, 1980), Rpp3 (Bromfield \& Melching, 1982), Rpp4 (Hartwig, 1986), Rpp5 (Garcia et al., 2008), and Rpp6 (Li et al., 2012). In addition, soybean cultivars carrying multiple (two or three) loci are also used (Paul et al, 2015; Yamanaka et al., 2013). The lack of a universal set of soybean host differentials limits the comparison of P. pachyrhizi pathotypes across the globe (Hartman et al., 2011). The emergence of novel rust pathotypes that overcome the major resistance genes (Akamatsu et al., 2017; Yorinori, 2008) limits the use of these cultivars in breeding, because they only confer resistance to a limited number of isolates (Hartman et al., 2005; Miles et al., 2008). Similar pathogenic diversity has been observed for other pathogens, such as Puccinia graminis f. sp. tritici, against which resistance broke down within a short period following deployment of particular resistance genes in breeding programmes (Singh et al., 2015).

Deployment of cultivars with durable resistance requires a comprehensive understanding of the prevalent pathotypes that occur in a particular region, due to the race-specificity of the available resistance genes. Variable numbers of $P$. pachyrhizi pathotypes have been reported in South America (Akamatsu et al., 2013), Japan (Yamaoka et al., 2014), and the USA (Twizeyimana \& Hartman, 2012). A study involving 83 isolates from Argentina, Brazil, and Paraguay, collected between 2010 and 2015 and tested on 16 host differentials, did not result in any identical virulence profiles (Akamatsu et al., 2017; Stewart et al., 2019). Thus, pathotypes identified in all these studies indicate existence of a high degree of variability among isolates of $P$. pachyrhizi across different parts of the world. In Africa, few studies have been conducted to determine the variability of $P$. pachyrhizi. To date, seven pathotypes have been reported in Nigeria and three in Uganda (Tukamuhabwa \& Maphosa, 2012; Twizeyimana et al., 2009). In Nigeria, three of the pathotypes were identified in all three regions that were surveyed, two of which accounted for the majority $(85 \%)$ of the isolates, and only one pathotype was unique for one of the regions. Four pathotypes were identified among a total of 17 isolates including those from Kenya, Malawi, South Africa, and Tanzania. The pathotype with the highest virulence complexity originated from South Africa, while the one with the lowest virulence complexity was found in Malawi and Tanzania (Murithi et al., 2017). Due to the dynamic nature of P. pachyrhizi, similar studies are required to provide more insight into pathogen diversity at a regional level to guide deployment of disease management strategies. The management of $P$. pachyrhizi may vary from country to country due to the differences in soybean growing seasons. Furthermore, cultivated soybean varieties differ across the region and this may complicate the deployment of resistant cultivars.

The objectives of this study were to evaluate (a) the diversity in virulence complexity of $P$. pachyrhizi populations in East Africa; (b) the prevalence and distribution of particular P. pachyrhizi pathotypes; and (c) the actual effectiveness of the Rpp genes against the $P$. pachyrhizi population currently existing in East Africa.

\section{2 | MATERIALS AND METHODS}

\section{1 | Field surveys, sample collection, and isolation of $P$. pachyrhizi strains}

Samples of P. pachyrhizi-infected leaves were collected across the major soybean-growing regions in Kenya (western region), Malawi (central and southern region), Tanzania (southern highlands and eastern region), and Uganda (central, eastern, western, and northern regions) in 2015, 2016, and 2017 growing seasons. Soybean plants were sampled at growth stages ranging from R4 (pod forming) to R6 (seed filling). In all locations, 5-10 random leaf samples bearing sporulating uredinia from each field and from different cultivars were air-dried, wrapped in paper towels, transported to the laboratory in a cooling box, and subsequently stored at $4^{\circ} \mathrm{C}$. Individual site details, including latitude, longitude, and elevation, were recorded using a hand-held GPS (eTrex 10; Garmin). 


\section{2 | Establishment of P. pachyrhizi single pustule isolates}

The recovered isolates were revived by hydrating overnight on a weigh boat placed in a Petri dish containing a few drops of water. The spores were used to inoculate the abaxial surface of healthy detached leaves of the universally susceptible soybean cultivar Soya 1. The inoculated leaves were placed on moist filter papers in a $30 \times 23 \times 5 \mathrm{~cm}$ transparent plastic container. The filter papers were kept moist by adding distilled water at 3-day intervals or when needed. To promote infection, the containers were first incubated in a tissue chamber (Percival Scientific, Inc.) in the dark for $24 \mathrm{hr}$ at $23^{\circ} \mathrm{C}$, followed by $12 \mathrm{hr}$ light/dark cycles at a temperature between 20 and $23^{\circ} \mathrm{C}$, and a humidity of $70 \%$ for 14 days. To purify the isolates, spores were collected from an isolated uredinium and were reinoculated and multiplied on fresh leaves of Soya 1 under similar conditions as described above.

\section{3 | P. pachyrhizi isolate characterization on soybean differentials}

The virulence spectrum of purified $P$. pachyrhizi isolates was assessed using 11 soybean host differentials carrying known rust resistance genes. The differential cultivars were obtained from the USDA Soybean Germplasm Collection and JIRCAS (Table 1). Soya 1 was used as a universally susceptible control. Four seeds of each of the 11 differential lines were sown in plastic pots filled with Professional Peatmoss (Kekilla), mixed with 10 mg 18:46:00: fertilizer (DAP). The plastic pots were placed in a growth chamber with a $12 \mathrm{hr}$ light/dark cycle, at a temperature between 22 and $25^{\circ} \mathrm{C}$ and humidity between $65 \%$ and $75 \%$, under rust-free conditions. Four-week-old leaflets from the second and/or third trifoliate leaves were used for inoculation. Plastic containers containing one leaflet from each of the 11 soybean differentials were used to inoculate a single P. pachyrhizi isolate. The experiment was arranged in a randomized complete block design with three replications for each isolate. For inoculation, the abaxial side of the leaflets was moistened with distilled water. Leaves bearing fresh sporulating uredinia from each isolate were lightly tapped to dislodge the spores onto the leaflets of the differentials. The inoculated leaflets were then incubated in a tissue culture chamber with similar conditions to those described above. To determine the ITs for each isolate, leaflets were observed under a stereomicroscope (Leica) at $80 \times$ magnification at 14 days after inoculation. The $P$. pachyrhizi ITs were classified as type 0 , immune (IM) reaction with no visible infection; type RB, resistant (avirulent) reaction, red-brown lesions with either no uredinia or sparsely sporulating uredinia; or type TAN, susceptible (virulent) reaction with tan lesions usually with many uredinia and abundant sporulation, as described by Twizeyimana et al. (2009). Sporulation levels were determined using a stereomicroscope (Leica) at $80 \times$ magnification. Sporulation levels of tan-coloured lesions were recorded based on a 0 to 3 scale (Yamanaka et al., 2010), where $0=$ no sporulation, $1=1-10$ lesions with spores (little), 2 = 11-15 lesions with spores

(moderate), and $3=>15$ lesions with spores (abundant).

\section{4 | Comparison of ITs among isolates collected from 2014 to 2016}

To evaluate the possible variation in virulence between isolates collected from the 2014 to 2016 cropping seasons, we selected P. pachyrhizi isolates collected from same regions in the respective years. The isolates were collected from sites that were about 5-10 km

TABLE 1 The set of soybean host differentials employed for determining the virulence spectrum of the collected Phakopsora pachyrhizi isolates, the resistant to P. pachyrhizi (Rpp) genes that they carry, their origin, and the frequency of virulence on a particular host differential of the different isolates used in this study

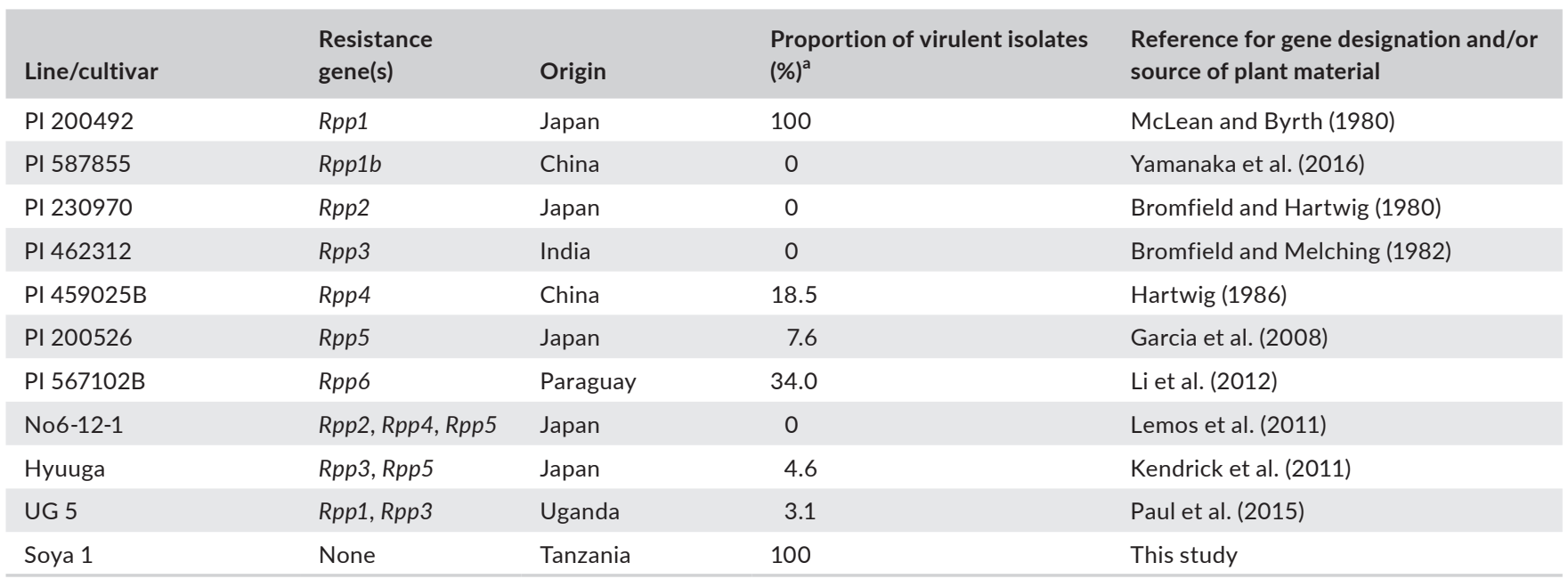

asolates that had a TAN infection type. 
apart in each region. The data on the ITs that were caused by isolates collected in 2014 were obtained from Murithi et al. (2017). To ensure uniformity of the data, we compared the ITs on seven identical host differentials for both studies, including PI 200492 (Rpp1), PI 462312 (Rpp3), PI 459025B (Rpp4), PI 200526 (Rpp5), PI 567102B (Rpp6), and the soybean cultivars Hyuuga (Rpp3, Rpp5) and UG 5 (Rpp1, Rpp5). Evaluation of the ITs was conducted as described above.

\section{5 | Analysis of P. pachyrhizi pathotype and virulence spectrum}

The three IT classifications (TAN, RB, and IM) were used to assign a pathotype to each P. pachyrhizi isolate that was obtained in our surveys. The octal nomenclature system (Goodwin et al., 1990) was used for pathotype classification, by coding "1" for TAN (compatible) while both RB and IM were coded "O" (incompatible) (Twizeyimana et al., 2009). The Habgood-Gilmour spreadsheet (HaGiS) program v. 3.1 (Hermann et al., 1999) was used to summarize the virulence data of each isolate by converting the data into an octal format. In this format, the 11 host differentials were arranged in groups of three, and assigned one octal digit as follows. The first octal digit contains PI 200492 (Rpp1), PI 587855 (Rpp1b), and PI 230970 (Rpp2); the second octal digit comprises PI 462312 (Rpp3), PI 459025B (Rpp4), and PI 200526 (Rpp5); the third octal digit consists of PI 567102B (Rpp6), cultivar Hyuuga (Rpp3, Rpp5), and UG 5 (Rpp1, Rpp3); and the fourth octal digit is represented by cultivar No6-12-1 (Rpp2, Rpp4, and Rpp5). Octal digits were assigned as follows: $000=0,100=1,010=2,001=4,110=3,101=5,011=6$, and $111=7$, sorted according to the number of virulence pattern per triplet. For example, an isolate with virulence phenotype 10000000000 was described by the octal code 1000 while 1000,111000 was represented by the octal code 1610 (as shown in Table 5). The virulence frequencies and mean virulence complexity (the average number of soybean differentials on which a given isolate is virulent) were calculated for each isolate.

\subsection{Statistical analysis}

Analysis of variance for disease severity was conducted using PROC GLIMMIX in SAS v. 9.3 (SAS Institute). Disease severity of the entire plant was based on the mean severity of the three canopy levels. The disease severity of five randomly selected plants in each plot was used for data analysis. Virulence diversity among countries was described by Shannon (H) (Shannon \& Weaver, 1949) and Simpson (S) (Simpson, 1949) indices of diversity calculated as follows: $H(A)=-$ $[(n i / N) \times \ln (n i / N)]$ and $S=\sum\left(n_{i}^{2}-n_{i}\right) /\left(N^{2}-N\right)$, where $n_{i}$ is the number of $P$. pachyrhizi isolates in the ith pathotype group and $N$ is the total number of $P$. pachyrhizi isolates in the population.The Euclidean distance matrix was calculated using R software v. 3.6.1 in default settings (R Development Core Team, 2019). The resulting matrices were entered into a hierarchical clustering function of the software. The unweighted pair group method with arithmetic mean
(UPGMA) was used to generate a dendrogram. The $\mathrm{R}$ package $\mathrm{pv}$ clust was executed to assess the uncertainty in hierarchical cluster analysis, which calculates $p$ values for each cluster using bootstrap resampling techniques.

\section{3 | RESULTS}

\section{1 | Field surveys, sample collection, and virulence spectrum of the various $P$. pachyrhizi isolates}

In the field surveys conducted in the 2015,2016 , and 2017 soybeangrowing seasons, a total of 150 isolates were collected from Kenya (37), Malawi (15), Tanzania (51), and Uganda (47). In all countries, the overall disease severity ranged between $5 \%$ and $90 \%$, the highest of which (20\%-90\%) was recorded in Uganda. A total of 65 isolates were eventually recovered from infected leaf samples that were collected from the four countries. The highest number of isolates recovered was from Kenya (25), followed by Uganda (18), Tanzania (15), and Malawi (7) (Table 2).

When tested on the 11 host differentials, all the 65 isolates were found to be virulent on the susceptible Soya 1 (Tables 1 and 2). Twelve (18.5\%) of the isolates were virulent on PI 459025B (Rpp4) and 23 (34\%) on PI 567102B (Rpp6), while less than 8\% of the isolates were virulent on PI 200526 (Rpp5). Four (57\%) of the isolates from Malawi, three (20\%) from Tanzania, and five (28\%) from Uganda were virulent on PI 459025B (Rpp4). Three (42\%) of the isolates from Malawi and two (13\%) of the isolates from Tanzania were virulent on PI 200526 (Rpp5). Ten (40\%) of the isolates from Kenya, five (71\%) from Malawi, four (27\%) from Tanzania, and three (17\%) from Uganda were virulent on PI 567102B (Rpp6) (Tables 1 and 2).

None of the isolates from Kenya were virulent on lines with the Rpp4 or Rpp5 loci. From the Kenyan isolates, $48 \%$ induced immune IT on cultivar No6-12-1, while all other isolates induced RB ITs on this cultivar, suggesting that this cultivar is highly resistant to the rust populations in Kenya. All the isolates were avirulent on PI 587855 (Rpp1b), PI 230970 (Rpp2), PI 462312 (Rpp3), and soybean cultivar No6-12-1, indicating that the corresponding resistance genes are effective against all rust pathotypes identified in this study and could therefore be used for developing durable resistance (Tables 1 and 2). Two Kenyan isolates, KE-17-01 and KE-17-03, were virulent on cultivars UG 5 and Hyuuga, while isolates KE-17-6 and KE-17-09 were virulent on Hyuuga but not on UG 5 (Table 2). Isolate KE-01-17 was avirulent on PI 462312 (Rpp3) and PI 200526 (Rpp5) but it was virulent on cultivar Hyuuga that contains both genes (Table 2).

\section{2 | Comparison of ITs caused by P. pachyrhizi isolates collected in East Africa from 2014 to 2016}

All the 34 isolates collected from Malawi and Tanzania caused a TAN IT on PI 200492 (Rpp1), while an RB IT was produced both on PI 462312 (Rpp3) and cultivar Hyuuga (Table 3). This again confirms 
TABLE 2 Infection types (ITs), virulence complexity, and pathotype of Phakopsora pachyrhizi isolates tested in East Africa on 11 soybean differentials, including the universally susceptible Soya 1 cultivar

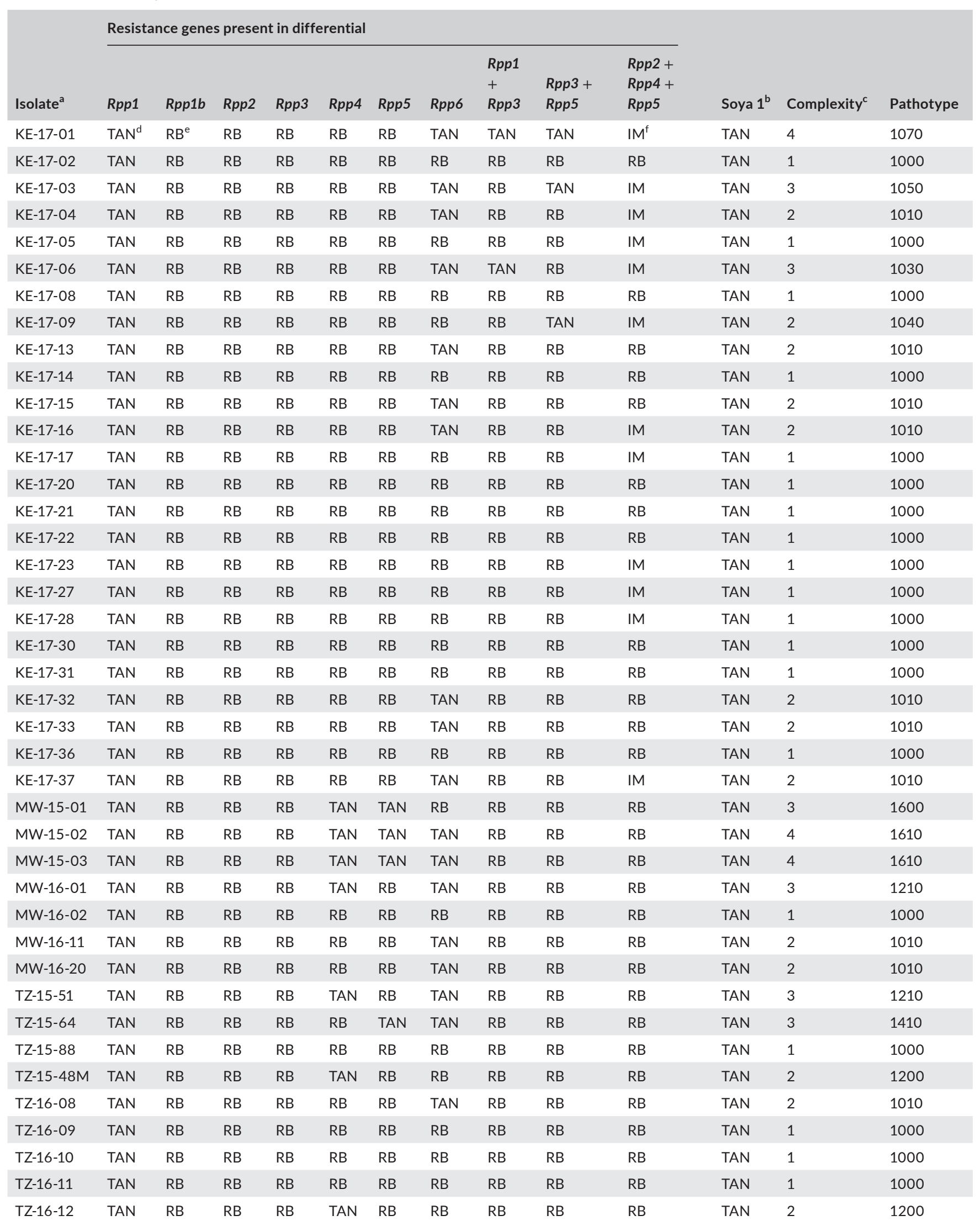


TABLE 2 (Continued)

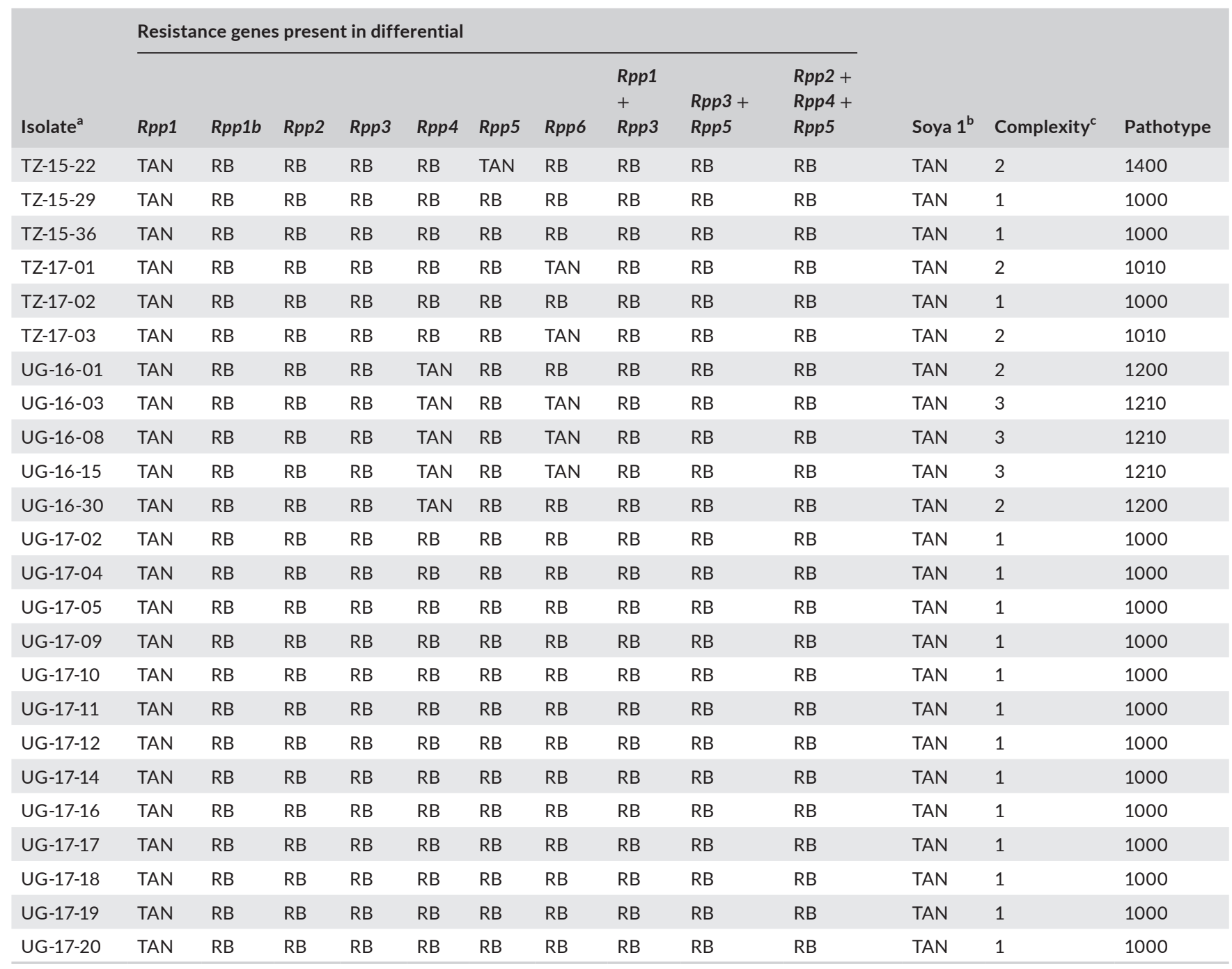

${ }^{a} K E$, Kenya; MW, Malawi; TZ, Tanzania; UG, Uganda.

bUniversally susceptible control.

${ }^{\mathrm{c}}$ Average number of soybean differentials on which a given isolate is virulent.

${ }^{\mathrm{d}}$ TAN: $\tan$ IT.

eRB: reddish-brown IT.

fIM: immune IT.

that the Rpp1 locus is ineffective, whereas the Rpp3 locus and cultivar Hyuuga (carrying Rpp3 and Rpp5) are highly effective against the rust populations in Malawi and Tanzania. All the isolates collected from Malawi over the years triggered a TAN IT on PI 459025B (Rpp4), except for one isolate (Table 3). Likewise, all 12 isolates from Tanzania collected in 2014 had TAN ITs on Rpp4, while from the seven isolates collected in 2015, two resulted in a TAN IT on the Rpp4-containing differential (Table 3). Interestingly, all five isolates collected in 2016 from Tanzania caused an RB IT on Rpp4. All six isolates collected in Malawi in 2014 and 2015 triggered a TAN IT on PI 200526 (Rpp5), while all four isolates collected in 2016 caused an RB IT (Table 3). Similar observations were made in Tanzania, where all 12 isolates collected in 2014 caused a TAN IT, whereas of the seven isolates collected in 2015, six caused an RB IT and only one caused a TAN IT on the Rpp5-containing soybean differential (Table 3). Only one isolate caused a TAN IT in 2016, while the other four caused an RB IT on this differential (Table 3).

In 2014, two of the P. pachyrhizi isolates collected in Malawi induced an RB IT on PI 567102B (Rpp6), while one induced an IM IT (Table 3). Of the three isolates collected in 2015, one resulted in an RB IT, while the other two produced a TAN IT on this differential. All but one isolate collected in 2016 in Malawi induced TAN ITs. For Tanzania, six (50\%) of the isolates collected in 2014 induced an RB IT, while the other six resulted in a TAN IT on the Rpp6 differential. In contrast, only one of the 12 isolates collected in 2015 and 2016 had a TAN IT, while the remainder of the isolates showed an RB IT (Table 3). The isolates from Malawi collected in 2014 caused an IM IT on UG 5 (carrying Rpp1 and Rpp3), while those collected in 2015 (three) and 2016 (four) produced an RB IT. Either an RB or an IM IT was observed on UG 5 when inoculated with the Tanzanian isolates 
TABLE 3 Comparison of infection types (ITs) among Phakopsora pachyrhizi isolates sampled during the 2014 to 2016 growing seasons in Malawi (MW) and Tanzania (TZ)

\begin{tabular}{|c|c|c|c|c|c|c|c|c|}
\hline \multirow[b]{2}{*}{ Isolate } & \multirow[b]{2}{*}{$\begin{array}{l}\text { Year of } \\
\text { collection }\end{array}$} & \multicolumn{7}{|c|}{ Resistance genes present in differential } \\
\hline & & Rpp1 & Rpp3 & Rpp4 & Rpp5 & Rpp6 & $\begin{array}{l}\text { Rpp3 + } \\
\text { Rpp5 }\end{array}$ & $\begin{array}{l}\text { Rpp1 + } \\
\text { Rpp3 }\end{array}$ \\
\hline MW-14-01 & $2014^{\mathrm{a}}$ & TAN & $\mathrm{RB}$ & TAN & TAN & $\mathrm{RB}$ & $\mathrm{RB}$ & IM \\
\hline MW-14-02 & & TAN & $\mathrm{RB}$ & TAN & TAN & $\mathrm{RB}$ & $\mathrm{RB}$ & IM \\
\hline MW-14-03 & & TAN & RB & TAN & TAN & IM & $\mathrm{RB}$ & IM \\
\hline MW-15-01 & 2015 & TAN & $\mathrm{RB}$ & TAN & TAN & RB & $\mathrm{RB}$ & RB \\
\hline MW-15-02 & & TAN & RB & TAN & TAN & TAN & $\mathrm{RB}$ & RB \\
\hline MW-15-03 & & TAN & RB & TAN & TAN & TAN & RB & RB \\
\hline MW-16-01 & 2016 & TAN & $\mathrm{RB}$ & TAN & $\mathrm{RB}$ & TAN & $\mathrm{RB}$ & RB \\
\hline MW-16-11 & & TAN & RB & TAN & $\mathrm{RB}$ & TAN & $\mathrm{RB}$ & RB \\
\hline MW-16-20 & & TAN & RB & TAN & $\mathrm{RB}$ & TAN & $\mathrm{RB}$ & RB \\
\hline MW-16-21 & & TAN & $\mathrm{RB}$ & $\mathrm{RB}$ & $\mathrm{RB}$ & $\mathrm{RB}$ & $\mathrm{RB}$ & $\mathrm{RB}$ \\
\hline TZ-14-01 & $2014^{a}$ & TAN & $\mathrm{RB}$ & TAN & TAN & TAN & $\mathrm{RB}$ & IM \\
\hline TZ-14-02 & & TAN & $\mathrm{RB}$ & TAN & TAN & TAN & $\mathrm{RB}$ & IM \\
\hline TZ-14-03 & & TAN & RB & TAN & TAN & TAN & $\mathrm{RB}$ & IM \\
\hline TZ-14-04 & & TAN & $\mathrm{RB}$ & TAN & TAN & TAN & $\mathrm{RB}$ & RB \\
\hline TZ-14-05 & & TAN & $\mathrm{RB}$ & TAN & TAN & TAN & $\mathrm{RB}$ & IM \\
\hline TZ-14-06 & & TAN & $\mathrm{RB}$ & TAN & TAN & TAN & $\mathrm{RB}$ & RB \\
\hline TZ-14-07 & & TAN & $\mathrm{RB}$ & TAN & TAN & RB & $\mathrm{RB}$ & RB \\
\hline TZ-14-08 & & TAN & $\mathrm{RB}$ & TAN & TAN & RB & $\mathrm{RB}$ & RB \\
\hline TZ-14-09 & & TAN & $\mathrm{RB}$ & TAN & TAN & $\mathrm{RB}$ & $\mathrm{RB}$ & RB \\
\hline TZ-14-10 & & TAN & $\mathrm{RB}$ & TAN & TAN & $\mathrm{RB}$ & $\mathrm{RB}$ & RB \\
\hline TZ-14-11 & & TAN & $\mathrm{RB}$ & TAN & TAN & $\mathrm{RB}$ & $\mathrm{RB}$ & RB \\
\hline TZ-14-12 & & TAN & $\mathrm{RB}$ & TAN & TAN & RB & $\mathrm{RB}$ & RB \\
\hline TZ-15-51 & 2015 & TAN & $\mathrm{RB}$ & TAN & RB & RB & $\mathrm{RB}$ & RB \\
\hline TZ-15-64 & & TAN & $\mathrm{RB}$ & RB & RB & RB & RB & RB \\
\hline TZ-15-88 & & TAN & $\mathrm{RB}$ & RB & RB & $\mathrm{RB}$ & $\mathrm{RB}$ & RB \\
\hline TZ-15-48M & & TAN & $\mathrm{RB}$ & TAN & RB & RB & $\mathrm{RB}$ & RB \\
\hline TZ-15-22 & & TAN & $\mathrm{RB}$ & RB & RB & $\mathrm{RB}$ & $\mathrm{RB}$ & RB \\
\hline TZ-15-29 & & TAN & RB & RB & TAN & RB & RB & RB \\
\hline TZ-15-36 & & TAN & $\mathrm{RB}$ & $\mathrm{RB}$ & $\mathrm{RB}$ & $\mathrm{RB}$ & $\mathrm{RB}$ & $\mathrm{RB}$ \\
\hline TZ-16-01 & 2016 & TAN & $\mathrm{RB}$ & RB & RB & TAN & $\mathrm{RB}$ & RB \\
\hline TZ-16-02 & & TAN & $\mathrm{RB}$ & RB & RB & $\mathrm{RB}$ & $\mathrm{RB}$ & RB \\
\hline TZ-16-08 & & TAN & RB & RB & RB & RB & RB & RB \\
\hline TZ-16-10 & & TAN & $\mathrm{RB}$ & RB & RB & RB & $\mathrm{RB}$ & RB \\
\hline TZ-16-11 & & TAN & RB & RB & $\mathrm{RB}$ & $\mathrm{RB}$ & $\mathrm{RB}$ & RB \\
\hline
\end{tabular}

${ }^{a}$ Infection type (IT) data for differentials originally reported by Murithi et al. (2017). collected in 2014, while those collected in 2015 and 2016 resulted in an RB IT only.

\section{3 | P. pachyrhizi pathotype evaluation, analysis, and distribution}

In total, 12 pathotypes were identified among the 65 P. pachyrhizi isolates tested in this study. Kenya and Tanzania had six pathotypes each, while five different pathotypes were identified in Malawi and three in Uganda (Table 4). Pathotype 1000 was the most frequent, with 35 isolates, representing $54 \%$ of all the collected isolates. This pathotype was found in all four countries. Pathotype 1010 was also frequently observed and included 12 (18\%) isolates in three countries, while the remaining pathotypes occurred infrequently and represented less than $8 \%$ of all the isolates.

About 56\% (14) of all isolates from Kenya and 72\% (13) of all isolates from Uganda belonged to pathotype 1000. Of the six pathotypes identified in Kenya, four $(1030,1040,1050,1070)$ were unique, as they were not found in any of the other countries, and 


\begin{tabular}{|c|c|c|c|c|c|c|}
\hline \multirow[b]{2}{*}{ Pathotype $^{a}$} & \multirow{2}{*}{$\begin{array}{l}\text { Virulence } \\
\text { complexity }^{\text {b }}\end{array}$} & \multicolumn{5}{|c|}{ Number of isolates } \\
\hline & & Kenya & Malawi & Tanzania & Uganda & Total \\
\hline 1000 & 1 & 14 & 1 & 7 & 13 & 35 \\
\hline 1010 & 2 & 7 & 2 & 3 & - & 12 \\
\hline 1030 & 3 & 1 & - & - & - & 1 \\
\hline 1040 & 2 & 1 & - & - & - & 1 \\
\hline 1050 & 3 & 1 & - & - & - & 1 \\
\hline 1070 & 4 & 1 & - & - & - & 1 \\
\hline 1200 & 2 & - & & 2 & 2 & 4 \\
\hline 1210 & 3 & - & 1 & 1 & 3 & 5 \\
\hline 1400 & 2 & - & - & 1 & - & 1 \\
\hline 1410 & 3 & - & - & 1 & - & 1 \\
\hline 1600 & 3 & - & 1 & - & - & 1 \\
\hline 1610 & 4 & - & 2 & - & - & 2 \\
\hline No. of isolates & - & 25 & 7 & 15 & 18 & 65 \\
\hline $\begin{array}{l}\text { No. of } \\
\text { pathotypes }\end{array}$ & - & 6 & 5 & 6 & 3 & 12 \\
\hline
\end{tabular}

TABLE 4 Pathotypes of Phakopsora pachyrhizi isolates sampled in East Africa, their virulence complexity, and distribution in different countries

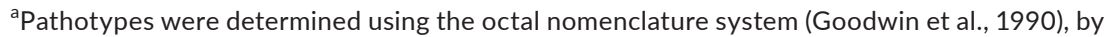
coding "1" for TAN reactions (susceptible), and "0" for IM and RB reactions (resistant).

${ }^{\mathrm{b}}$ Average number of soybean differentials on which a given isolate is virulent.

each was represented by one isolate. In the same way, pathotypes 1600 and 1610 were unique for Malawi and were represented by one and two isolates, respectively. Pathotype 1200 was unique for Uganda and Tanzania, while pathotypes 1400 and 1410 were only found in Tanzania. Pathotype 1210 was found in all countries except Kenya.

Virulence complexity varied between 1 and 4, with the majority of the isolates (54\%) having a complexity of 1 (Table 4). A virulence complexity of 2 or 3 was observed for $42 \%$ of the isolates tested, while only $4.6 \%$ of the $P$. pachyrhizi isolates had a virulence complexity of 4. Pathotypes 1070 and 1610, found in Kenya and Malawi, respectively, were virulent on four of the 10 host differentials, being Rpp1, Rpp4, Rpp5, and Rpp6, while pathotype 1000 was virulent on only one of the differentials (Rpp1) (Table 5). Pathotype 1070 was virulent on Rpp6 and on both the cultivars UG 5 and Hyuuga, while pathotype 1030 was virulent on Rpp6 and on cultivar UG 5. Additionally, more than $50 \%$ of the isolates were virulent on Rpp6, indicating that this differential may be used to distinguish the majority of the isolates from this region. Our results indicated that pathotypes 1040 and 1070 , both of which were virulent on cultivar Hyuuga (carrying both Rpp3 and Rpp5), were avirulent on the soybean differentials carrying only Rpp3 or Rpp5 (Table 5).

The UPGMA dendrogram, based on Euclidean distance, clustered isolates into 10 major groups (Figure 1). The clusters seemed to be more related to the pathotype of the isolate. Group IV was composed of the majority of the isolates (35) drawn from all four countries and belonging to pathotype 1000 , while Group V was the next most populous, comprising 12 isolates drawn from three of the four countries, and consisting of isolates from pathotype 1010. Some groups comprised a single isolate, including Group 1 (KE-17-06),
Group III (KE-17-09), and Group VII (MW-15-01). Shannon's (H) and Simpson's $(S)$ indices of diversity based on the number of pathotypes indicated that the isolates from Malawi were more diverse $(H=1.55$, $S=0.90)$, while those from Uganda were less diverse $(H=0.78$, $S=0.46)$ (Table 6)

\section{4 | DISCUSSION}

To deploy durable resistance, knowledge of the virulence spectrum that exists in the local P. pachyrhizi population is required. We investigated the virulence diversity of $P$. pachyrhizi isolates using a set of 11 soybean differentials and identified 12 different pathotypes among the 65 isolates collected from East Africa, suggesting that $P$. pachyrhizi populations across East Africa are highly dynamic. Results from this study form the basis for guiding the deployment of the available resistance genes in the management of $P$. pachyrhizi in the region, and underscores the need to screen for novel sources of resistance.

Virulence of $P$. pachyrhizi isolates on the soybean differentials supports the observation that various strains have evolved that overcome the resistance conferred by the majority of the resistance loci worldwide (Yorinori, 2008). For instance, resistance conferred by Rpp1 was overcome within three years after its discovery in Australia (Hartman et al., 2011). This observation is consistent with previous reports that described all P. pachyrhizi isolates from Africa and some isolates from South America as virulent on plants that carry Rpp1 (Akamtsu et al., 2013; Bonde et al., 2006; Murithi et al., 2017; Twizeyimana et al., 2009). Although Rpp1 was ineffective against most African isolates, it may still confer resistance to rust 
TABLE 5 Virulence profile and frequency of pathotypes of Phakopsora pachyrhizi isolates collected in East Africa and tested on 11 soybean differentials, including a universally susceptible Soya 1

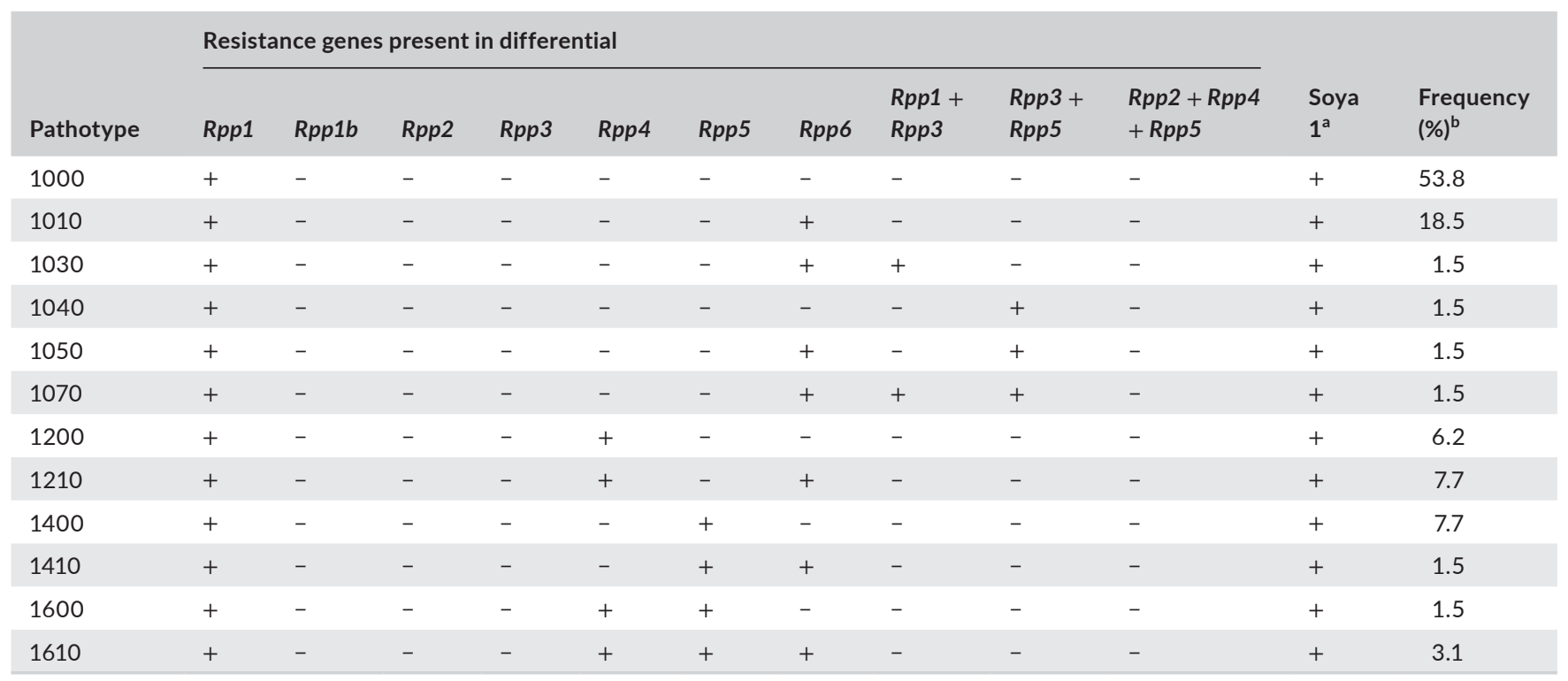

aUniversally susceptible control; +, compatible interaction; -, incompatible interaction.

${ }^{\mathrm{b}}$ Pathotype frequency.

TAB LE 6 Shannon's $(H)$ and Simpson's $(S)$ indices for diversity among Phakopsora pachyrhizi populations

\begin{tabular}{|lllll|}
\hline Country & $\begin{array}{l}\text { No. of } \\
\text { isolates }\end{array}$ & $\begin{array}{l}\text { No. of } \\
\text { pathotypes }\end{array}$ & H & S \\
\hline Kenya & 25 & 6 & 1.20 & 0.63 \\
\hline Malawi & 7 & 5 & 1.55 & 0.90 \\
\hline Tanzania & 15 & 6 & 1.49 & 0.76 \\
\hline Uganda & 18 & 3 & 0.78 & 0.46 \\
\hline
\end{tabular}

Note $H$ and $S$ were calculated as and $S=1-\sum\left(n_{i}^{2}-n_{i}\right) /\left(N^{2}-N\right)$ where $n_{i}$ is the number of isolates in the ith pathotype group and $N$ is the total number of isolates in the population.

isolates from Japan, Mexico, and the USA (Peña-del-Río et al., 2014; Twizeyimana \& Hartman, 2012; Yamaoka et al., 2014).

For the first time, isolates that are virulent on cultivars UG 5 (carrying Rpp1 and Rpp3) and Hyuuga (carrying Rpp3 and Rpp5) (Kendrick et al., 2011; Paul et al., 2015) were identified in Kenya. Previously, P. pachyrhizi isolates from Nigeria, Uganda, and the USA were found to induce an IM reaction on cultivar UG 5 (Twizeyimana \& Hartman, 2012; Twizeyimana et al., 2009). Virulence on UG 5 and Hyuuga could be due to the emergence of pathotypes that may have developed as a result of mutation, recombination, immigration, or direct selection (McDonald \& Linde, 2002).

The high frequency of pathotype 1000 in East Africa may be attributed to limited genetic variation among $P$. pachyrhizi, caused by the use of a single resistance gene over a long time. This may have selected for this particular pathotype and has shaped P. pachyrhizi to be present with low diversity in the region. Deployment of similar resistance genes over large areas was, for example, shown to contribute to the uniform virulence spectra among a global collection of wheat stripe rust (Puccinia striiformis f. sp. tritici) isolates (Sharma-Poudyal et al., 2013).

Pathotypes 1040 and 1070 were both virulent on cultivar Hyuuga, which has a natural combination of the Rpp3 and Rpp5 loci (Kendrick et al., 2011). It is surprising that both pathotypes were avirulent on soybean differentials carrying either Rpp3 or Rpp5. Pathotype 1070 was also virulent on UG 5 that contains Rpp1 and Rpp3. Although pathotype 1070 is virulent on Rpp1, it is avirulent on Rpp3. This suggests that the Rpp 3 and Rpp5 alleles in UG 5 and Hyuuga are different from those in PI 462312 and PI 200526, respectively. Multiple alleles of Rpp5 have previously been reported and the Rpp5 locus and recognition spectrum in PI 200526 was found to be different from the one present in Hyuuga (Kendrick et al., 2011). Likewise, although the Rpp3 gene in PI 462312 maps to the same locus as in Hyuuga, they possess different recognition specificities (Kendrick et al., 2011), and are therefore probably not identical. Interestingly, Hyuuga is a cross between Akasaya and Ako Musume (Hossain et al., 2014). Akasaya (PI 416764) is a Japanese soybean landrace with a resistance locus similar to Rpp3, which clusters with PI 462312 (Rpp3) (Hossain et al., 2014). Although these two accessions are closely related, some Argentinian P. pachyrhizi isolates caused different ITs on these accessions (Akamatsu et al., 2013). Likewise, a Brazilian isolate produced a TAN IT on PI 462312, while it caused an RB IT on PI 506764 (Silva et al., 2008). Our results corroborate these earlier observations, and therefore PI 462312 and PI 506764 probably carry different alleles of the Rpp3 locus. This suggests that the Rpp3 and Rpp5 resistance loci in Hyuuga convey a different recognition specificity and are probably allelic variants of the Rpp3 and Rpp5 loci present in PI 462312 and PI 200526, respectively. 


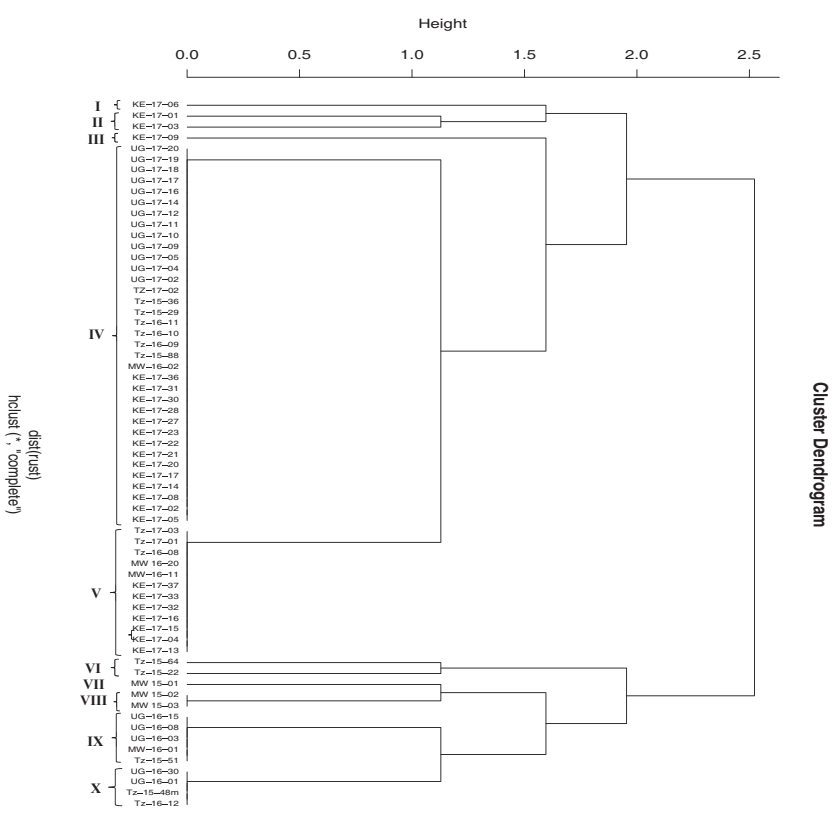

FIGURE 1 Cluster dendrogram of the 65 Phakopsora pachyrhizi isolates from six different countries based on their virulence on the differential set of soybean lines. Cluster analysis was performed using R software v. 3.2.0 (R Development Core Team, 2019). The distance matrix was entered into a hierarchical clustering function of the software and the dendrogram was constructed using the minimum variance (Ward's method)

In this study, a cultivar with a stack of three resistance loci was tested for the first time against $P$. pachyrhizi isolates from Africa and found to be immune. This finding is consistent with reports on the resistance of the No6-12-1 cultivar against isolates from Brazil and Japan (Yamanaka et al., 2015). Cultivar No6-12-1 originates from Japan and contains three resistance loci: Rpp2, Rpp4, and Rpp5 (Lemos et al., 2011). Arguably, the stacking of multiple major resistance genes helps to cope with the rapid evolution of pathogen virulence, as the pathogen will have to mutate multiple avirulence genes simultaneously to gain virulence on plants with the stacked $R$ genes. This becomes less likely with the deployment of several novel resistance genes. Therefore, stacking of resistance genes is likely to enhance the durability of the resistance of soybean against $P$. pachyrhizi (McDonald \& Linde, 2002; Mundt, 2014). Nevertheless, some of the gene combinations, like Rpp1 + Rpp2 + Rpp4, were found to be ineffective against a highly virulent Brazilian isolate (Yamanaka et al., 2015). Thus, careful selection of the resistance gene combinations is important to develop durable resistance. Furthermore, as most genes are deployed individually already, the pathogen may overcome each of these resistance genes in a sequential fashion.

The present study identified soybean with the $R p p 1 b, R p p 2$, or Rpp3 resistance genes and the cultivar No6-12-1 (carrying Rpp2, Rpp4, and Rpp5) as the most suitable plant material for deployment in the African soybean breeding programme. Rpp1b, Rpp2, and Rpp3 are effective, for instance, in Japan (Yamanaka et al.,
2010; Yamaoka et al., 2014), the USA (Paul et al., 2015), Nigeria (Twizeyimana et al., 2009), Tanzania, Malawi (Murithi et al., 2017), and Uganda (Maphosa et al., 2012). Although Rpp2 and Rpp3 are ineffective in South America (Akamatsu et al., 2013; Yorinori, 2008), our study confirms that they provide resistance to $P$. pachyrhizi isolates in East Africa, and therefore can be deployed in soybean breeding programmes. However, care needs to be taken to prevent the introduction of South American P. pachyrhizi isolates into Africa.

Cultivar UG 5 has been widely used in breeding programmes in Nigeria and Uganda. However, the susceptibility of this cultivar to some of the Kenyan isolates implies that its use might be short-lived, as pathotypes that are also virulent on UG 5 have emerged. Similarly, although cultivar Hyuuga was previously identified as a suitable candidate for breeding programmes in Africa (Murithi et al., 2017), the susceptibility of this cultivar to some of the Kenyan isolates tested in this study implies that the Rpp3 and Rpp 5 combination may no longer be effective against isolates from Kenya.

The results of our study reveal the highly dynamic virulence diversity among $P$. pachyrhizi isolates. Although the diversity in some of the countries in this study was much lower based on the Shannon's and Simpson's indices, our study provides a basis for further research to understand P. pachyrhizi diversity in Africa. It also calls for a consistent surveillance of the virulence profile of the occurring strains in order to understand the changes that continuously occur in the field and to inform breeders on the most suitable resistance genes to deploy. Pyramiding of the most effective resistance genes should be pursued for developing the most durable and most broad-spectrum resistance against $P$. pachyrhizi.

\section{ACKNOWLEDGEMENTS}

Wycliffe Waswa (IITA-Kenya), Dr Phinehas Tukamuhabwa (Makerere University), Serapia Mhanje (CARITAS-Tanzania), and Edwin Chatama (IITA-Malawi) helped with logistic support during field surveys. Mary Njala (IITA-Tanzania) provided technical skills during field and laboratory work. Some of the soybean host differentials were provided by Dr Yamanaka (JIRCAS). This research was funded by the International Institute of Tropical Agriculture (IITA), by a Lukas Brader Scholarship Award, and the 2Blades Foundation at The Sainsbury Laboratory, Norwich, UK.

\section{CONFLICT OF INTEREST}

The authors declare no conflict of interest.

\section{DATA AVAILABILITY STATEMENT}

The data that support the findings of this study are available from the corresponding author upon reasonable request.

\section{ORCID}

Harun M. Murithi (ID https://orcid.org/0000-0001-7455-1188 George Mahuku iD https://orcid.org/0000-0001-8444-8651 Matthieu H. A. J. Joosten iD https://orcid.org/0000-0002-6243-4547 


\section{REFERENCES}

Abate, T., Alene, A., Bergvinson, D., Shiferaw, B., Silim, S., Orr, A. et al. (2012) Tropical grain legumes in Africa and South Asia: Knowledge and opportunities. Nairobi, Kenya: ICRISAT.

Akamatsu, H., Yamanaka, N., Soares, R.M. \& Ivancovich, A.J.G. (2017) Pathogenic variation of South American Phakopsora pachyrhizi populations isolated from soybeans from 2010 to 2015. Japanese Agricultural Research Quarterly, 51, 221-232.

Akamatsu, H., Yamanaka, N., Yamaoka, Y., Soares, R.M., Morel, W., Ivancovich, A.J.G. et al. (2013) Pathogenic diversity of soybean rust in Argentina, Brazil, and Paraguay. Journal General Plant Pathology, 79, 28-40.

Bonde, M.R., Nester, S.E., Austin, C.N., Stone, C.L., Frederick, R.D., Hartman, G.L. et al. (2006) Evaluation of virulence of Phakopsora pachyrhizi and Phakopsora meibomiae isolates. Plant Disease, 90, 708-716.

Bromfield, K.R. \& Hartwig, E.E. (1980) Resistance to soybean rust and mode of inheritance. Crop Science, 20, 254-255.

Bromfield, K.R. \& Melching, J.S. (1982) Sources of specific resistance to soybean rust. Phytopathology, 72, 706.

Dean, R., Van Kan, J.A., Pretorius, Z.A., Hammond-Kosack, K.E., Di Peitro, A., Spanu, P.D. et al. (2012) The top 10 fungal pathogens in molecular plant pathology. Molecular Plant Pathology, 13, 413-430.

FAOSTAT. (2018) Food and Agricultural Organization of United Nations (FAO) database. Available at: http://www.fao.org/faostat/en/\#data/ QC. [Accessed 24 November 2020]

Garcia, A., Calvo, E.S., Kiihl, R.A.D., Harada, A., Hiromoto, D.M. \& Vieira, L.G.E. (2008) Molecular mapping of soybean rust (Phakopsora pachyrhizi) resistance genes: discovery of a novel locus and alleles. Theoretical and Applied Genetics, 117, 545-553.

Godoy, C.V., Seixas, C.D.S., Soares, R.M., Marcelino-Guimaraes, F.C., Meyer, M.C. \& Costamilan, L.M. (2016) Asian soybean rust in Brazil: past, present, and future. Pesquisa Agropecuária Brasileira, 51, 407-421.

Goodwin, S., Allard, R.W. \& Webster, R.K. (1990) A nomenclature for Rhynchosporium secalis pathotypes. Phytopathology, 80, 1330-1336.

Hartman, G.L., Hill, C.B., Twizeyimana, M., Miles, M.R. \& Bandyopadhyay, R. (2011) Phakopsora pachyrhizi, the cause of soybean rust. 6, no. 025.CAB Reviews: Perspectives in Agriculture, Veterinary Science, Nutrition and Natural Resources.

Hartman, G.L., Miles, M.R. \& Frederick, R.D. (2005) Breeding for resistance to soybean rust. Plant Disease, 89, 664-666.

Hartwig, E.E. (1986) Identification of a 4th major gene conferring resistance to soybean rust. Crop Science, 26, 1135-1136.

Hermann, A., Lower, C.F. \& Schachtel, G.A. (1999) A new tool for entry and analysis of virulence data for plant pathogens. Plant Pathology, 48, 154-158.

Hossain, M.M., Akamatsu, H., Morishita, M., Mori, T., Yamaoka, Y., Suenaga, K. et al. (2014) Molecular mapping of Asian soybean rust resistance in soybean landraces PI 594767A, PI 587905 and PI 416764. Plant Pathology, 64, 147-156.

Isard, S.A., Russo, J.M. \& Arriati, A. (2007) The integrated aerobiology modeling system applied to spread of soybean rust into Ohio River valley in September 2006. Aerobiologia, 23, 271-282.

Kawuki, R.S., Adipala, E. \& Tukamuhabwa, P. (2003) Yield loss associated with soybean rust (Phakopsora pachyrhizi Syd.) in Uganda. Journal of Plant Pathology, 151, 7-12.

Kendrick, M.D., Harris, D.K., Ha, B.K., Hyten, D.L., Cregan, P.B. Frederick, R.D. et al. (2011) Identification of a second Asian soybean rust resistance gene in Hyuuga soybean. Phytopathology, 101, 535-543.

Kumudini, S., Godoy, C.V., Board, J.E., Omielan, J. \& Tollenaar, M. (2008) Mechanisms involved in soybean rust-induced yield reduction. Crop Science, 48, 2334-2342.

Lemos, N.G., Braccini, A.L., Abdelnoor, R.V., Oliveira, M.C.N., Suenaga, K. \& Yamanaka, N. (2011) Characterization of genes Rpp2, Rpp4, and Rpp5 for resistance to soybean rust. Euphytica, 182, 53-64.
Levy, C. (2005) Epidemiology and chemical control of soybean rust in southern Africa. Plant Disease, 89, 669-674.

Li, S., Smith, J.R., Ray, J.R. \& Frederick, R.D. (2012) Identification of a new soybean rust resistance gene in PI567102B. Theoretical and Applied Genetics, 12, 133-142.

Lin, S.Y. (1966) Studies on the physiologic races of soybean rust fungus, Phakopsora pachyrhizi Syd. Journal of Taiwan Agriculture Research, 51, 24-28.

Maphosa, M., Talwana, H. \& Tukamuhabwa, P. (2012) Enhancing soybean rust resistance through Rpp2, Rpp3 and Rpp 4 pairwise gene pyramiding. African Journal of Agricultural Research, 30, 4271-4277.

McDonald, B.A. \& Linde, C. (2002) Pathogen population genetics, evolutionary potential and durable resistance. Annual Review of Phytopathology, 40, 349-379.

McLean, R. \& Byrth, D.E. (1980) Inheritance of resistance to rust (Phakopsora pachyrhizi) in soybeans. Australasian Journal of Agriculture Research, 31, 951-956.

Miles, M.R., Morel, W., Ray, J.D., Smith, J.R., Frederick, R.D. \& Hartman, G.L. (2008) Adult plant evaluation of soybean accessions for resistance to Phakopsora pachyrhizi in the field and greenhouse in Paraguay. Plant Disease, 92, 96-105.

Mundt, C.C. (2014) Durable resistance: a key to sustainable management of pathogens and pests. Infection, Genetics and Evolution, 27, 446-455.

Murithi, H.M., Beed, F., Soko, M., Haudenshield, J. \& Hartman, G.L. (2015) First report of Phakopsora pachyrhizi causing rust on soybean in Malawi. Plant Disease, 99, 420.

Murithi, H.M., Haudenshield, J., Beed, F., Mahuku, G., Joosten, M.H.A.J. \& Hartman, G.L. (2017) Virulence diversity of Phakopsora pachyrhizi isolates from East Africa compared to a geographically diverse collection. Plant Disease, 101, 1194-1200.

Paul, C., Frederick, R.D., Hill, C.B., Hartman, G.L. \& Walker, D.R. (2015) Comparison of pathogenic variation among Phakopsora pachyrhizi isolates collected from the United States and international locations, and identification of soybean genotypes resistant to the U.S. isolates. Plant Disease, 99, 1059-1069.

Peña-del-Río, M.L.Á., Maldonado-Moreno, N. \& Díaz-Franco, A. (2014) Reaction of germplasm to Phakopsora pachyrhizi in the field. Revista Fitotecnia Mexicana, 37, 225-227.

R Development Core Team. (2019). R: A language and environment for statistical computing. Vienna, Austria: R Foundation for Statistical Computing. Available at: http://www.R-project.org/ [Accessed 24 November 2020]

Shannon, C. \& Weaver, W. (1949) The mathematical theory of communication. Urbana: University of Illinois Press.

Sharma-Poudyal, D., Chen, X.M., Wan, A.M. \& Zhan, G. (2013) Virulence characterization of international collections of the wheat stripe rust pathogen, Puccinia striiformis f. sp. tritici. Plant Disease, 97, 379-386.

Silva, D.C.G., Yamanka, N., Brogin, R.L., Arias, C.A.A., Nepomuceno, A.L., Di Mauro, A.O. et al. (2008) Molecular mapping of two loci that confer resistance to Asian soybean rust in soybean. Theoretical and Applied Genetics, 117, 57-63.

Simpson, E.H. (1949) Measurement of diversity. Nature, 163, 688.

Singh, R.P., Hodson, D.P., Jin, Y., Lagudah, E.S., Ayliffe, M.A., Bhavani, S. et al. (2015) Emergence and spread of new races of wheat stem rust fungus: continued threat to food security and prospects of genetic control. Phytopathology, 105, 872-884.

Stewart, S., Rodríguez, M. \& Yamanaka, N. (2019) Pathotypic variation of Phakopsora pachyrhizi isolates from Uruguay. Tropical Plant Pathology, 44, 309-317.

Tukamuhabwa, P. \& Maphosa, M. (2012) State of knowledge in breeding for resistance to soybean rust in the developing world. Rome, Italy: FAO. FAO Plant Production and Protection Paper 204.

Twizeyimana, M. \& Hartman, G.L. (2012) Pathogenic variation of Phakopsora pachyrhizi isolates on soybean in the United States from 2006 to 2009. Plant Disease, 96, 75-81. 
Twizeyimana, M., Ojiambo, P.S., Sonder, K., Ikotun, T., Hartman, G.L. \& Bandyopadhyay, R. (2009) Pathogenic variation of Phakopsora pachyrhizi infecting soybean in Nigeria. Phytopathology, 99, 353-361.

Wen, L., Bowen, C.R. \& Hartman, G.L. (2017) Prediction of short-distance aerial movement of Phakopsora pachyrhizi urediniospores using machine learning. Phytopathology, 107, 1187-1198.

Yamanaka, N., Lemos, N.G., Uno, M., Akamatsu, H., Yamaoka, Y. \& Abdelnoor, R.V. (2013) Resistance to Asian soybean rust in soybean lines with the pyramided three Rpp genes. Crop Breeding and Applied Biotechnology, 13, 5-82.

Yamanaka, N., Morishita, M., Mori, T., Lemos, N.G., Hossasin, MdM, Akamatsu, H. et al. (2015) Multiple Rpp-gene pyramiding confers resistance to Asian soybean rust isolates that are virulent on each of the pyramided genes. Tropical Plant Pathology, 40, 283-290.

Yamanaka, N., Morishita, M., Mori, T. \& Muraki, Y. (2016) The locus for resistance to Asian soybean rust in PI 587855. Plant Breeding, 135, 621-626.

Yamanaka, N., Yamaoka, Y., Kato, M. \& Lemos, N.G. (2010) Development of classification criteria for resistance to soybean rust and differences in virulence among Japanese and Brazilian rust populations. Tropical Plant Pathology, 35, 153-162.

Yamaoka, Y., Yamanaka, N., Akamatsu, H. \& Suenaga, K. (2014) Pathogenic races of soybean rust Phakopsora pachyrhizi collected in Tsukuba and vicinity in Ibaraki, Japan. Journal of General Plant Pathology, 80, 184-188.

Yorinori, J.T. (2008) Soybean germplasm with resistance and tolerance to Asian rust and screening methods. In: Kudo, H., Suenaga, K., Soares, R.M. \& Toledo, A. (Eds.) Facing the challenge of soybean rust in South America. JIRCAS Working Report No. 58. Tsukuba, Japan: JIRCAS, pp. 70-87.

How to cite this article: Murithi HM, Soares RM, Mahuku G, van Esse HP, Joosten MHAJ. Diversity and distribution of pathotypes of the soybean rust fungus Phakopsora pachyrhizi in East Africa. Plant Pathol. 2020;00:1-12. https://doi. org/10.1111/ppa.13324 